Article

\title{
The Asymmetrical Effect of Polarization on Support for Independence: The Case of Catalonia
}

\author{
Juan Rodríguez-Teruel * and Astrid Barrio \\ Department of Constitutional Law, Political and Administrative Sciences, University of Valencia, Spain; \\ E-Mails: jrteruel@uv.es (J.R.-T.), astrid.barrio@uv.es (A.B.) \\ * Corresponding author
}

Submitted: 25 June 2021 | Accepted: 18 September 2021 | Published: 10 December 2021

\begin{abstract}
The article analyses the consequences of elite polarization at the mass level in the centre-periphery dimension. We analyse the rapid rise in support for independence in Catalonia, focusing on the role of party competition around the centreperiphery cleavage. We argue that mainstream actors' adoption of centrifugal party strategies with respect to the national question produced a polarizing dynamic in the party system that eventually caused voters' attitudes regarding the centre-periphery issue to harden. Indeed, we posit that this increase in mass polarization was a consequence of party agency that subsequently helped to drive attitudes regarding independence. To test this hypothesis, we measure centreperiphery polarization (as perceived by voters) by adopting two different perspectives-inter-party distances (horizontal polarization) and party-voter distances (vertical polarization)-and then run logistic regressions to explain support for independence. The findings show an asymmetrical effect on polarization. While the centrifugal strategy implemented by Catalan regionalist parties paved the way for a radicalization of voters on the Catalan nationalist side, among voters for non-regionalist parties, attitudes towards independence were initially less conditioned by this polarization. The results provide evidence of the political effects of elite polarization.
\end{abstract}

\section{Keywords}

Catalonia; independence; party competition; party cues; polarization; secession

\section{Issue}

This article is part of the issue "Secessionism in Liberal Democracies: What Do We Really Know About the Explanations of Secessionism?" edited by Ferran Requejo (Pompeu Fabra University, Spain) and Marc Sanjaume-Calvet (Pompeu Fabra University, Spain / Open University of Catalonia, Spain).

(C) 2021 by the authors; licensee Cogitatio (Lisbon, Portugal). This article is licensed under a Creative Commons Attribution 4.0 International License (CC BY).

\section{Introduction}

How does party politics contribute to increasing support for independence in a democratic country? The literature on secession has tended to emphasize the role of socioeconomic and institutional factors or "preconditions" in explaining demands for independence (Wood, 1981), particularly in countries that have experienced recent processes of decentralization. This perspective usually implies that these demands remain stable over time, as a consequence of ethnic divisions produced in the formation of modern states and the survival of peripheral identities (Flora et al., 2007). However, recent examples of growing calls for independence referendums indicate the relevance of political agency (like leadership or party demands) in these secessionist movements.

In this article, we argue that party competition is a powerful driver of a sudden, rapid increase in secessionist demands among the population (Pagoaga Ibiricu, 2020). In a context where secession was not previously a salient issue and did not enjoy significant support among citizens, the role of party agency may become critical for boosting support for independence when political 
parties decide to adopt centrifugal strategies concerning this subject for different reasons. Such centrifugal competition in the centre-periphery cleavage, in combination with other factors, may transform voters' preferences for greater self-government into explicit support for secession. The key driver connecting party competition and changes in ideological attitudes is polarization, defined here as a shift in political attitudes towards more extreme positions (Campbell, 2016; Dalton, 2008; Sartori, 1976).

In this respect, we assume that mass polarization is a possible result of the decisions made by political elites, whereby parties send cues to their voters, frame arguments regarding the political alternatives and define the political agenda (Druckman et al., 2013). The role of polarization in the context of rising secessionism has recently been analysed from the perspective of moderate voters, showing that intense radicalization after a territorial crisis has caused many such voters' attitudes to harden (Guntermann \& Blais, 2020). However, we turn our attention to the early stages of a secessionist crisis. Taking the case of Catalonia, we aim to observe the extent to which recent support for secession here (which has traditionally been low) has been affected by the inter-party competition that emerged among Catalan regionalist parties in previous years. Between 2010 and 2012, Catalonia experienced a dramatic increase in support for secession, growing from $15-20 \%$ to almost $50 \%$, in the process transforming the political debate around decentralization in Spain and producing a major political crisis that culminated in the events of October 2017, when regional autonomy was suspended after the Catalan government unilaterally declared the region's independence.

Previous studies have shown that the territorial clash in Catalonia was preceded by years of party changes in their position regarding the centre-periphery issue, strategic behaviour, and ethnic outbidding, particularly in the case of Convergència i Unió (CiU), the main regionalist party, which until that point had defended moderate, non-secessionist positions (Barrio \& Rodríguez-Teruel, 2014, 2017; Colomer, 2018; Elias, 2015; Elias \& Mees, 2017; Miley, 2014). As was also the case in Quebec and Scotland, the result was a growth in party polarization in the centre-periphery cleavage. However, the effects of this polarization were asymmetrical. Rooted in regionalist parties' cues and framing strategies, this polarization made it easier for many regionalist voters to embrace secession. By contrast, non-regionalist parties tempered their initial push for independence from their political adversaries, possibly resulting in a vaguer effect on their voters. Hence, our argument tries to connect this centrifugal party competition with the resulting rise in demand for independence. Therefore, we observe whether voters' perceptions of party polarization affected their support for more radical attitudes regarding the territorial issue. To test this relationship, we analyse political attitudes at the beginning of the cri- sis in 2012 and observe the effect of polarization on voters' preferences. The results confirm a robust effect in that election, particularly among CiU's voters.

The article is organized as follows. First, we provide some theoretical arguments about party competition and polarization in the context of secessionist movements. Then we sketch the origins of political polarization in Catalonia until 2012, before presenting our hypotheses and variables. The fifth section empirically assesses the consequences of polarization for support for secession. The conclusion discusses the role of polarization in the light of these findings.

\section{Secession, Party Competition, and Polarization}

\subsection{The Role of Parties in Increasing Demands for Secession}

When secessionist movements arise, it is typical for there to be many factors pushing in that direction. Early studies on secession and ethnic conflicts highlighted the relevance of regional inequalities in driving demands for self-government (Horowitz, 1985). In addition, most scholars have shown that identity and ethnic divisions are important preconditions for the development of secessionist movements (Bond, 2000), although this relationship is complex and multifaceted (Blais et al., 1992; McCrone \& Paterson, 2002; Serrano, 2013). Hence, economic variables only seem to be relevant for pro-secessionist parties when linguistic divisions are involved as well (Álvarez Pereira et al., 2018). In the same vein, political decentralization may incentivize demands for self-government where ethnic divisions are politically relevant (Brancati, 2006; Massetti \& Schakel, 2013). Recent studies focusing on economic attitudes have identified the material calculus held by some individuals when considering the effects of secession (Hierro \& Queralt, 2021; Muñoz \& Tormos, 2015). Overall, these structural explanations help us to understand the formation of secessionist claims and individuals' territorial preferences over time.

However, the evolution of demands for secession is also conditioned by political actors' behaviour. The way in which a state responds to such threats is crucial to determining the latter's success (Griffiths, 2016). More generally, secession may be a rational goal for political leaders seeking office and material benefits (Collier \& Hoeffler, 2002; Hechter, 2000). Hence, leaders may send cues to their voters (Muñoz \& Tormos, 2015) and use framing techniques to persuade the masses to choose a separatist view as a strategic response to an ethnically charged collective action problem in a union (Hale, 2008). This can pave the way for ethnic outbidding in order to mobilize ethnic groups to favour secession (Rabushka \& Shepsle, 1972).

The perspective of ethnic outbidding studies brings political parties and party competition to the centre when aiming to explain secession and ethnic conflicts. 
As a consequence, it becomes possible to understand the contexts in which regionalist or "ethnonational" parties choose to join a centrifugal dynamic of party competition based on ethnic outbidding (Zuber \& Szöcsik, 2015). Territorial or national polarization may be one of the strategies parties use to compete, although their choice also depends on the strategies adopted by their opponents (Pagoaga Ibiricu, 2020). The outbidding thesis has been applied successfully to recent cases of secession crises in Western Europe (Barrio \& Rodríguez-Teruel, 2017; Coakley, 2008; Gormley-Heenan \& Macginty, 2008; Mitchell et al., 2009; Sanjaume-Calvet \& Riera-Gil, 2020).

However, previous studies have tended to fail to empirically show the mechanism linking outbidding competition with the rise in support for secession in the short term. Several scholars have stressed the role of party cues (Bullock, 2020) as mechanisms of opinion formation among poorly informed individuals on complex issues (Hellström, 2008), although the relationship between parties and public opinion may work in both directions: Parties influence voters' attitudes, but they also pay attention to their voters' opinions (Steenbergen et al., 2007).

As a consequence, party polarization may stimulate polarization among voters with respect to specific issues. In this vein, the present article aims to explore whether party-driven polarization regarding the national issue really works in this context as an explanatory driver of increased support for independence, as long as we can observe a distinct effect on national preferences among more polarized individuals.

\subsection{The Role of Polarization in Stimulating Demands for Secession}

We define polarization as the increase in ideological or policy distance among voters and parties, across the ideological spectrum of any given polity, in such a way as to decisively shape how political forces compete within the party system (Campbell, 2016; Dalton, 2008; Sartori, 1976). Polarization usually denotes, implicitly or explicitly, three different components: an ideological distance among parties, voters, or both; an element of extremism related to the presence of anti-system forces; and parties' internal homogeneity (Schmitt, 2016, p. 3). The most common approach analyses ideological polarization based on inter-party distances in the left-right dimension, although ideological differences may also be measured according to other dimensions and related to specific issues, such as the centre-periphery cleavage (Lauka et al., 2018).

In empirical terms, ideological polarization is usually treated as an aggregated feature of the party system (Dalton, 2008). In order to analyse it at the individual level, we can distinguish two dimensions of elite polarization (Lupu, 2015; Rodríguez-Teruel, 2021). On the one hand, horizontal polarization measures the ideological distances between parties as perceived by each individual, i.e., a voter's perception of the extent of elite polarization. On the other hand, vertical polarization captures the distance between each voter and each party, as perceived by that voter, i.e., how far party elites are from a voter's position. These two dimensions of polarization at the individual level help to better capture how voters perceive party ideological movements (change or stability) as a consequence of political competition.

Polarization between elites and voters may work in either direction. From a spatial perspective, some studies have shown that polarization among voters drives political parties to extremes in an attempt to gain or keep their support (Cox, 1990; Ezrow, 2007). More recent studies have argued instead that party competition may adopt centrifugal dynamics, resulting in a more polarized electorate (Hetherington \& Weiler, 2010; Lupu, 2015). Party cues may play a role in this party-driven polarization, following "partisan-motivated reasoning," i.e., the tendency for ordinary citizens to adopt the policy preferences of their closest parties (Bolsen et al., 2014; Druckman et al., 2013). Nevertheless, party identification is not a necessary precondition for individuals to be persuaded by parties, as Guntermann (2017) has shown in the case of Spanish voters regarding the centreperiphery issue. These party cues are particularly likely to affect voters' opinions if an issue is considered salient (Nord $\varnothing, 2021$ ).

Challenger parties are especially likely to adopt centrifugal strategies to compete with mainstream forces by emphasizing polarizing issues, like immigration or anti-establishment rhetoric (de Vries \& Hobolt, 2020; Morales et al., 2015; Szöcsik \& Polyakova, 2018). However, mainstream parties may react by choosing similar polarizing strategies, in an attempt to contain their electoral losses (de Lange, 2012; Downes \& Loveless, 2018; Rodríguez-Teruel, 2021). As a consequence of this centrifugal competition, voters may adopt clearer positions in those issues emphasized by parties (Bischof \& Wagner, 2019), while mainstream parties may have a chance of mitigating their electoral losses because greater party system polarization can reduce party switching (Dejaeghere \& Dassonneville, 2017).

What are the consequences of such centrifugal dynamics when political parties compete around the centre-periphery cleavage through ethnic outbidding? Following the cues provided by their preferred parties, those voters with a particularly clear perspective of party distances may adopt less ambiguous positions in their policy preferences. For instance, they may move towards explicit support (in the case of regionalist voters), or alternatively strongly oppose secession (in the case of non-regionalist voters). By contrast, voters who continue to observe minimal distance between parties (or between parties and themselves) may be more sceptical of the consistency or credibility of more radical positions (i.e., support for or opposition to secession) declared by parties. In such cases, the importance of 
polarization, among other factors, becomes blurred. This argument departs from traditional accounts of recent Catalan politics that observe political polarization simply as a consequence of the secessionist crisis (Balcells et al., 2021). Instead, we suggest that it was the outcome of previous centrifugal competition and then became a driver of changes in political attitudes and political realignment. Anchoring national polarization as an outcome of built-up political tension is important for our argument, as it helps to avoid potential endogeneity problems in the relationship between polarization and policy preferences. Therefore, before entering into the details of how our expectation can be tested, we will sketch out how centrifugal party competition had produced a context for party polarization and thereby paved the way for strengthening voters' perceptions of polarization around the centre-periphery cleavage.

\section{Centrifugal Party Competition in Catalonia Until 2012}

Catalonia has often been considered a relevant case study for observing successful decentralization in an old unitarian state or, alternatively, as a case of a threat to national unity in spite of regional autonomy (Colino, 2020; Dowling, 2018). Although the region has been ruled by regionalist parties since the recovery of self-governance, support for secession has traditionally remained relatively weak, below $20 \%$, in contrast to strong positions in favour of the constitutional system of devolved powers, as seen in Figure 1. In spite of this sta- ble support for the status quo, Catalan parties launched a reform of the Statute of Autonomy in 2004, seeking more political and fiscal powers (Gray, 2020). The reform took more than two years and produced a huge political controversy in Spain. Interestingly, during those years the debate around devolution temporarily fuelled support for federalism among a significant proportion of voters, to the detriment of the status quo (Figure 1).

Although the new statute was finally passed via referendum in 2006 with high support but low turnout (in contrast to the previous statute of 1978), the Spanish mainstream conservative party Partido Popular (PP, People's Party) appealed against the text before the Constitutional Court. The Court issued a ruling in 2010 declaring some articles to be unconstitutional. One year later, the Spanish conservatives achieved a big majority in the national parliament. The new executive took a tough position against regional governments and launched a number of attempts to recentralize political power, with the aim of reducing the public budget in response to the Great Recession. In this context, support for secession in Catalonia received a major boost between 2010 and 2012. When asked which relationship with Spain they would prefer, the proportion of individuals in support of secession increased from $20 \%$ to almost $50 \%$ by the end of 2012 , while more than $50 \%$ said they would vote "yes" in the event of an independence referendum (Figure 1). This massive switch in favour of secession occurred without significant changes in the traditional factors mentioned above, including identity. So, what happened?

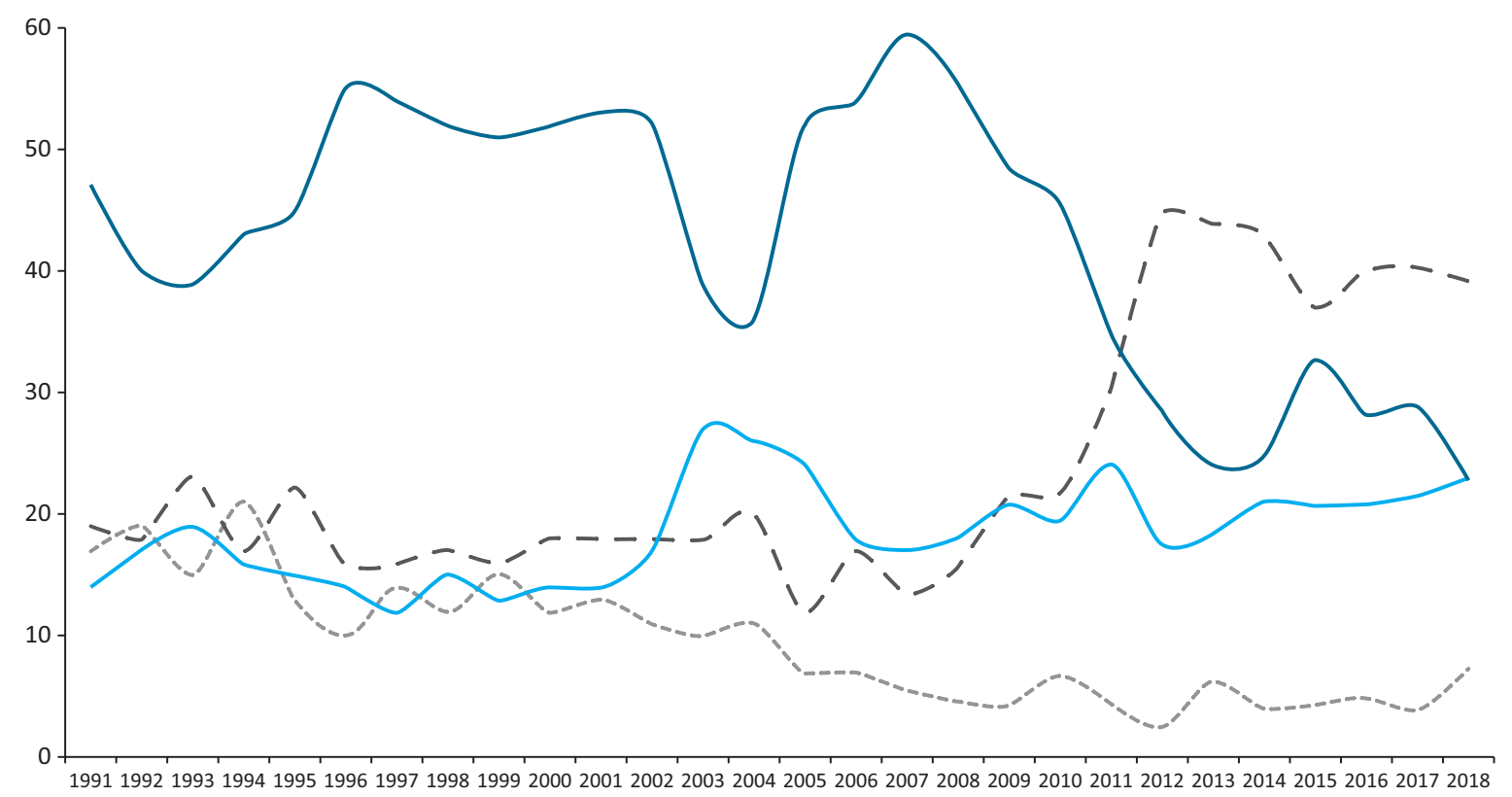

\begin{tabular}{|ll|}
\hline---- A region within Spain & - A state within a federal Spain \\
- Autonomous Community & -
\end{tabular}

Figure 1. Preferences for models of territorial organization in Catalonia. Source: Authors' elaboration using ICPS's database (https://www.icps.cat). 
General accounts of this period usually refer to contextual factors-such as the aforementioned 2010 Constitutional Court's ruling and the Great Recessionas the critical events explaining the rapid growth in support for secession over a short period of time. Academic studies show a more complex perspective, in which identity is the most powerful independent variable, although economic preferences and expectations may also play an additional modest role tied to identity (Muñoz \& Tormos, 2015; Rico \& Liñeira, 2014; Serrano, 2013). More recently, some studies have highlighted the relevance of competition among regionalist parties in the previous decade as a source of elite polarization preceding the territorial clash (Barrio \& Rodríguez-Teruel, 2014; Colomer, 2018; Pagoaga Ibiricu, 2020).

In particular, Barrio and Rodríguez-Teruel (2017, pp. 1783-1785) have identified three stages in the ethnic outbidding launched by these parties. A first step was taken in 2000-2003, when Catalan parties initiated a debate concerning the reform of self-government in the region. This was originally regarded by some parties as a mere reform aimed at updating certain aspects and was quickly accepted by most of them as a potential opportunity to introduce a constitutional change in the Spanish model of decentralization without requiring constitutional reform (Colino, 2009). In reality, however, the debate was instrumental for the opposition in Catalonia to weaken the political collaboration between the Catalan right-wing regional party Convergencia i Unió (CiU, Convergence and Union) and the PP, as both were initially reluctant or opposed to such a reform. The goal was finally achieved in December 2003, when the left-wing opposition parties made an agreement to form a new executive coalition rooted in a pledge to reform the Statute of Autonomy. The second step occurred between 2004 and 2006, when the region's political parties became embroiled in a tortuous process of reform that soon became an outbidding process between $\mathrm{CiU}-$ which by this time was part of the opposition-and the pro-secession Esquerra Republicana de Catalunya (ERC, Catalan Republican Left), which was in government. Hence, $\mathrm{CiU}$ pushed the bargaining of the reform beyond the constitutional limits set by the ruling parties in order to destabilize the ruling cabinet coalition (Keating \& Wilson, 2009; Orte \& Wilson, 2009). Finally, between 2007 and 2012, CiU and ERC progressively adopted more radical positions in the territorial dimension, becoming more critical of the new statute and more explicitly in favour of an independence referendum in the short term. This turn was particularly overwhelming in the case of Convergència Democràtica de Catalunya (CDC, Catalan Democratic Convergence)-the main member of CiUwhich in 2012 adopted a pro-secession position. Thus, in a decade the main historically moderate, regionalist political force of Catalonia had moved from pragmatic regionalism to independentism without there being a parallel change in its voters' opinions.

It is important to note that this process of increasing centrifugal party competition in Catalonia was followed by slightly significant changes in the polarization



Figure 2. Party system polarization in the left-right dimension and the national dimension. Source: Authors' elaboration using CIS's post-electoral surveys based on Dalton's Polarization Index (see the Appendix). 
of the party system (measured using Dalton's polarization index; see the Supplementary File). As seen in Figure 2, perceived polarization in the centre-periphery cleavage increased smoothly throughout the decade at both the elite and the mass level and measured in terms of both the left-right dimension and the national dimension. National polarization has usually been slightly higher than the left-right dimension. At the party level, the difference between left-right and national polarization increased particularly significantly after 2006. While the left-rightweighted distances among parties and voters remained unchanged overall, the rise in national polarization was related to the centrifugal dynamics perceived by individuals, especially regarding the emerging party in those years, Ciudadanos (Citizens) - a party that represented tough opposition to Catalan nationalism-and CiU, along with its party successors. These two forces exemplify the divergent paths followed by Catalan parties in the national dimension as perceived by the electorate (Figure 3 ). This evolution suggests that the pattern of party radicalization between 2006 and 2012 was part of a general trend that brought all political parties further from the centre at the zenith of the secession crisis in 2017.

As a consequence, individual perceptions of polarization increased over the course of the decade. Interestingly, this evolution was not necessarily consistent across the electorate. As seen in Figure 4, the trend was clearer in the vertical dimension than in the horizontal dimension as well as among voters from non-regionalist parties. Hence, regionalist voters tended to exhibit higher rates of horizontal polarization, i.e., they saw larger differences between parties compared to non-regionalists' perceptions. As for the vertical dimension, some parties developed stronger perceptions of the ideological distances between themselves and the parties of the system. Indeed, PP's, Ciudadanos', ERC's, and CiU's voters all showed higher rates of vertical ideological distances, which steadily increased from 2003. By contrast, those who voted for more moderate parties-like Partit dels Socialistes de Catalunya (PSC, Catalan Socialist Party) and Iniciativa Catalunya Verds (ICV, Initiative for Catalonia Greens)-manifested lower perceptions of polarization.

However, by 2012 all party electorates achieved the highest levels of vertical and horizontal polarization in the series. This was the result of the policy change in the territorial issue adopted by CiU in competition with ERC, as between 2010 and 2012 both parties included explicit demands for a secession referendum within their electoral platforms, framing these demands in terms of democracy, justice, and necessity (to solve the economic crisis). Interestingly, this evolution was not replicated to the same extent by the non-regionalist parties-even though parties like PSC, PP, and particularly Ciudadanos each had a clear position against secession-as they usually downplayed or did not give credibility to such demands, often describing the secessionists' momentum as a "soufflé" (Paz, 2012). Some parties (PSC, ICV) even accepted the possibility of holding a sort of referendum on devolution. Hence, in those years, centrifugal competition came mostly from Catalan regionalist forces, while non-regionalists instead tended to emphasize the
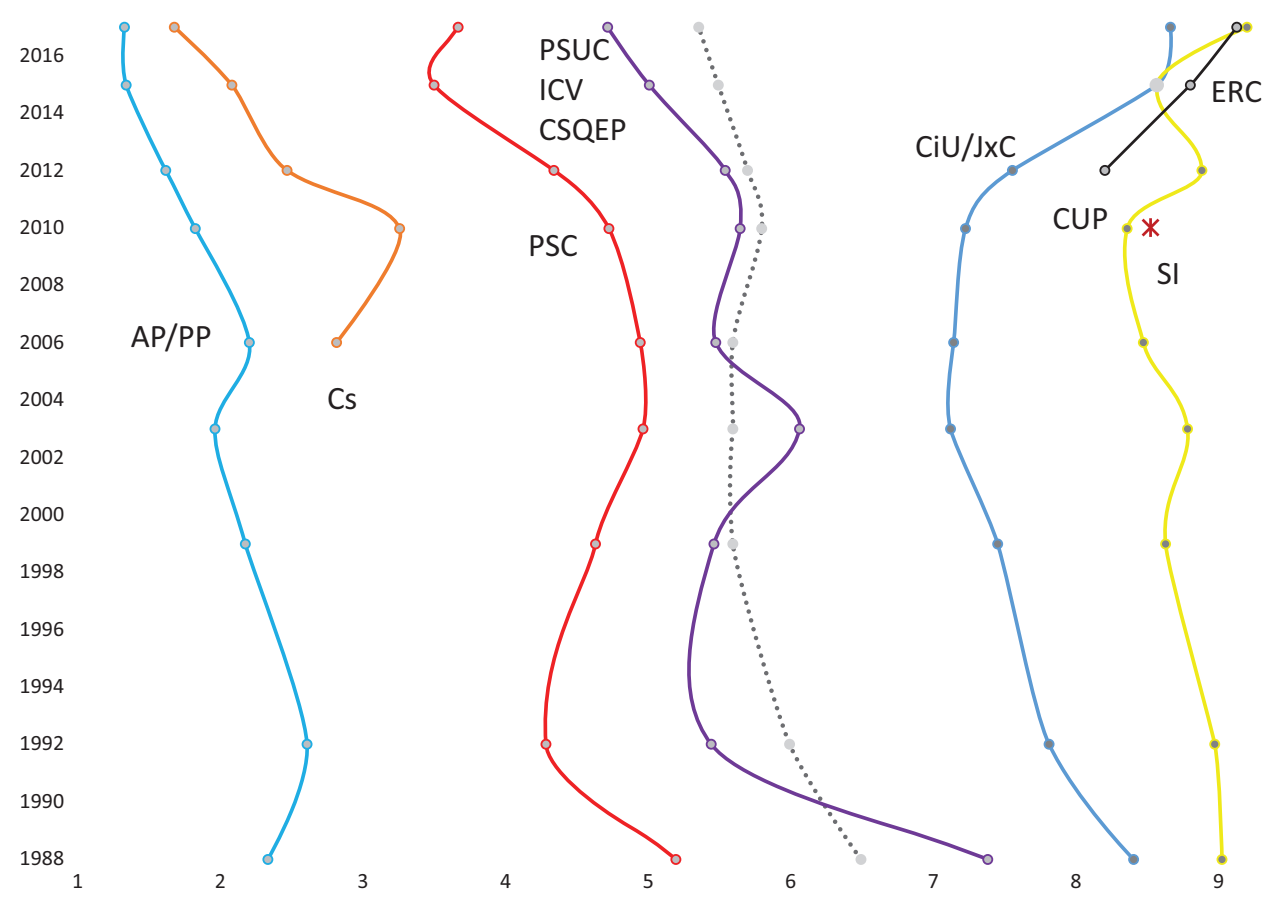

10

Figure 3. Party position in the national dimension-according to voters-in Catalonia. Notes: Parties are located according to voters' view in an axis where 10 is the highest level of Catalan nationalism and 0 the lowest; the dotted line shows voters' own position. Source: Authors' elaboration using CIS's post-electoral surveys. 


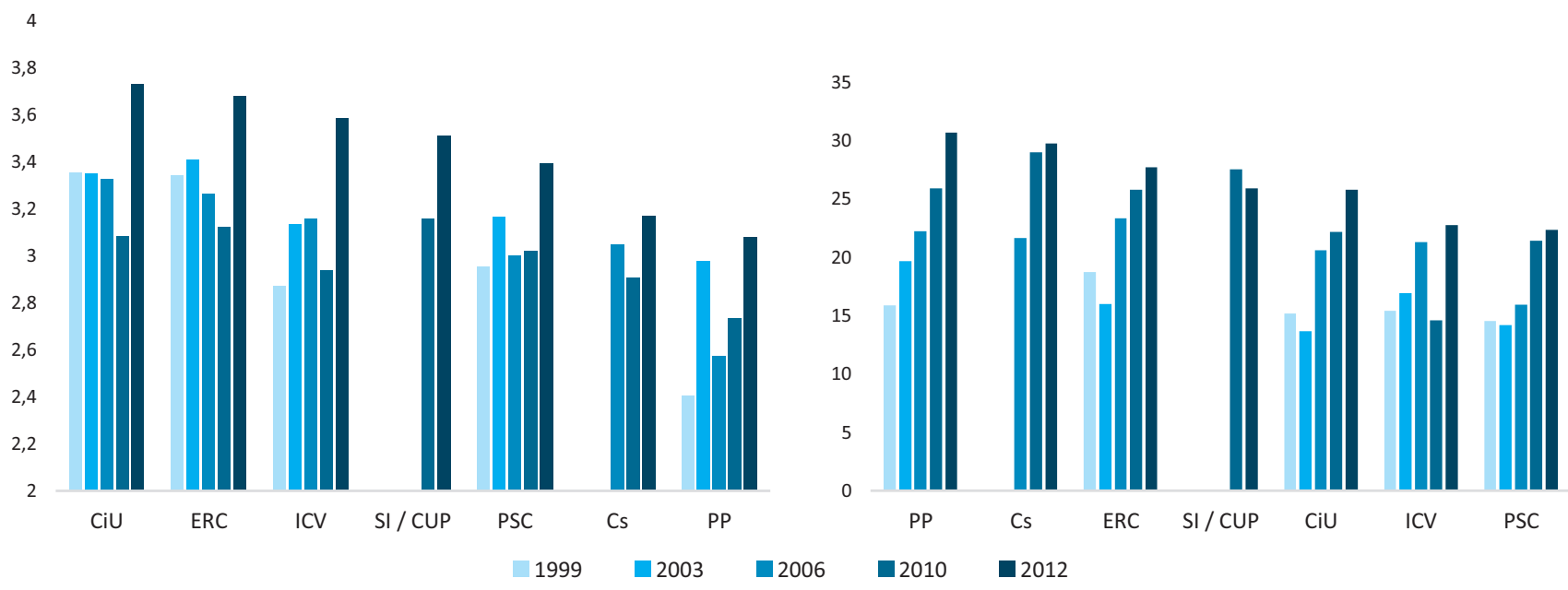

Figure 4. Evolution of horizontal (right) and vertical (left) polarization by parties. Source: Authors' elaboration using CIS's post-electoral surveys based on polarization indexes (see Section 4).

economy and the need to overcome the Great Recession. The mottos selected for the 2012 election reflected these different approaches. Indeed, whereas ERC explicitly mentioned secession ("vote for independence") and CiU defended "the will of the people," PSC presented itself as "the reasonable alternative" and both PP and Ciudadanos stated the idea of "better together" (Barrio et al., 2018).

Overall, this political context was defined by centrifugal dynamics of party competition fed by regionalist forces as well as a pattern of increasing perceived distances between parties and between parties and voters. In the next section, we will attempt to connect this pattern with changes in individuals' preferences regarding the national issue.

\section{Hypotheses, Data, and Methods}

This study employs the concept of polarization to capture how individuals perceived changes in party positions in the national cleavage as a consequence of the centrifugal party competition held in the previous decade, as introduced in Section 3. The effect of these perceptions of party positions can be better understood under the light provided by party cues. Such cues may operate as heuristics for voters, reducing the costs of expressing opinions with regard to controversial issues (Lupia, 1994). Parties may also influence opinions through partisan-motivated reasoning, as mentioned in Section 2.2, when voters adopt parties' positions because they identify with them and want to continue supporting them (Bolsen et al., 2014). In this vein, several analysts have suggested that the progressive adoption by $\mathrm{CiU}$ of the demand for $\mathrm{a}$ secession referendum (and its support for secession as well) made it easier for many of this party's voters to move towards the same position (Martí, 2013; Rico \& Liñeira, 2014), even where they already had a "crystallized" position (Guntermann, 2017). Hence, after years of criticism raised by regionalist parties against the con- stitutional Spanish framework, sending cues about their evolution towards more radical positions and adopting frame strategies to legitimate the new demands for a vote on secession, these parties were able to persuade most of their voters that they were truly committed to their new claims for independence. On the other side of the party system, non-regionalist parties were less convinced of this policy turn and initially decided to simply wait for the secessionist momentum to vanish (which did not happen).

Therefore, according to the political portrait presented in the previous section, our general expectation is that (perceived) polarization impelled many voters towards clearer positions regarding the national issue. However, this effect might have differed depending on voters' orientations, particularly with regard to their preferred party. While polarization might have initially been a source of support for independence among regionalist voters $\left(\mathrm{H}_{1}\right)$, it is less likely that it played the same strong role to foster hard opposition against secession among those non-regionalist parties' voters $\left(\mathrm{H}_{2}\right)$. Hence, the party cues provided by regionalist parties regarding the issue should have made it easier for regionalist voters to perceive greater distances among parties in the centre-periphery cleavage. As a consequence, regionalist voters with higher perceptions of horizontal polarization should have been more likely to support secession $\left(\mathrm{H}_{1 \mathrm{a}}\right)$. An alternative way of observing the effect of polarization is by considering the importance of the party cues provided by one's own party in reinforcing one's perceptions of its distances from other parties that do not share the same approach. Accordingly, support for secession should have increased as regionalist voters perceived that their positions regarding the national issue had moved further away from most of the parties: vertical polarization $\left(\mathrm{H}_{1 \mathrm{~b}}\right)$. Both hypotheses assume that polarization initially affected potential supporters of secession more than those who remained sceptical or opposed. Alternatively, if polarized perceptions spread 
equally among all subsets of regionalist voters from the beginning, we should expect a non-significant effect of polarization (null hypothesis).

Given that the non-regionalist parties had more reactive positions regarding the territorial issue than their regionalist counterparts, as most of them did not exclusively focus on this issue, and given that some of them (e.g., PSC) entered the debate with moderate positions (for instance, not completely rejecting the idea of a referendum), we can expect that polarization produced a less sharp effect regarding support for secession among non-regionalist voters. Hence, given that these voters perceived smaller differences among parties and the different subsets of non-regionalist voters' perceptions regarding vertical polarization were more heterogeneous, we should expect a weaker or irrelevant (negative) impact of both horizontal $\left(\mathrm{H}_{2 \mathrm{a}}\right)$ and vertical $\left(\mathrm{H}_{2 b}\right)$ polarization on their territorial preferences. Alternatively, the null hypothesis for this second expectation is that polarization produced the same equivalent (but opposite) effect in both electorates. This null hypothesis would mean that non-regionalist voters would also adopt polarized positions and would indeed oppose secession in the same extent than regionalist voters expressed support for it.

As several scholars have shown, identity is a fundamental driver of secession. Therefore, we should expect identity not only to have a positive effect, but also to act as a multiplier of the polarization effect among regionalist voters, as radicalization among regionalist parties should be particularly persuading to those with a strong Catalan national identity $\left(\mathrm{H}_{3}\right)$. Hence, to observe this additional effect we will introduce an interaction between these two variables in our general model.

To estimate the impact of polarization at the individual level, we employ two different indicators. Horizontal polarization (the perceived distance between parties) is operationalized with Lupu's (2015) index of perceived party polarization, as the sum of the weighted average distances between each pair of parties:

$$
\text { Horizontal Polarization }=\sum_{k=1}^{m-1} \sum_{j=1}^{m} \frac{w_{j}+w_{k}}{m-1}\left|p_{j}-p_{k}\right|
$$

where $j$ and $k$ are different parties, $p_{j}$ and $p_{k}$ are the ideological positions the respondent assigned parties $j$ and $k$ in the left-right axis, $w_{j}$ and $w_{k}$ are their vote shares, and $m$ is the number of parties the respondent placed.

In addition, vertical polarization measures the aggregated distances between each individual and each party, as perceived by the former. We measure it using our own estimation of the average of the sum of the distances between the voter and each party:

$$
\text { Vertical Polarization }=\frac{\sum_{j=1}\left(v-p_{j}\right)}{m}
$$

where $v$ is the voter's self-placement and $p_{j}$ is the ideological position of each political party (as perceived by the same voter) in the left-right axis, while $m$ is the number of parties the respondent placed.

The research uses survey data from CIS' postelectoral studies concerning the Catalan elections in 2012. We also use $\mathrm{CIS}^{\prime}$ post-electoral studies of previous regional elections in Catalonia since 1999 to estimate the polarization indices. They include questions to elicit respondents' opinions of the centre-periphery cleavage (the dependent variable) and the extent of Catalan nationalism (the main independent variable), measured using an index from 1 to 10 (where 10 is the maximum level of Catalan nationalism); individuals give their own position as well as those of the main parties. We utilize this index to compute the variables with respect to polarization and run logistic regression models to estimate the effects on the three dependent variables.

Our dependent variable is support for secession. We build a dummy variable from an original categorical variable asking which kind of territorial arrangement is preferable for Spain, among five options: no decentralization at all, less decentralization, status quo, more decentralization, or the possibility of self-determination for regions aiming to become an independent state. The last option is usually taken as support for independence (or at least the chance to decide via referendum).

The research hypotheses assume different effects of polarization on the dependent variable depending on voters' choice of political party. Hence, our models will be run on two different sets of voters: regionalist parties and non-regionalist parties. The first group comprises those who in 2012 voted for either CiU, ERC, or Candidatura d'Unitat Popular (CUP, Candidacy of Popular Union), a radical left-wing party supporting independence. These parties were more clearly aligned in favour of an independence referendum in the 2012 electoral campaign. The second group comprises PSC, PP, and Ciudadanos. These parties have traditionally been opposed to independence and defend Catalonia's union with Spain. We do not include within these groups those who voted for ICV, a regionalist party with links to the Spanish radical left that is not formally in favour of secession but is amenable to discussing terms for a referendum. Alternatively, to check the robustness of our results we will observe the differences depending on the vote held in 2010 (reported by individuals in 2012). In the same vein, we will employ data from CIS' 2010 post-electoral study E2857 and include the indicators used in the 2012 survey.

Our models include several control items, like gender, age, profession, education, and town size. More importantly, the models also control for the main explanations provided by previous studies: birthplace (in Catalonia or elsewhere), main language employed (Catalan, Spanish, both, or other), criticism of the economic situation, and, above all, national identity (measured using the Moreno-Linz question, which distinguishes individuals feeling only Spaniard or only Catalan, more Spaniard than Catalan and vice versa, or as Catalan as Spaniard). 


\section{Empirical Findings}

If regionalist parties-and particularly $\mathrm{CiU}-$ were embroiled in centrifugal competition, thereby polarizing the electorate's political attitudes, did this polarization play a role in fostering support for secession? To test our hypotheses, we regress support for secession by different types of polarization and other control variables with opinion data from 2012. Figure 5 plots the average marginal effects of each dimension of polarization according to each group of voters (the results for the full models are reported in Tables $A 2$ and $A 3$ in the Supplementary File).

Indeed, the results show that both horizontal and vertical national polarization had a significant effect on support for secession. Hence, all things being equal, an increase of one unit in perceived distance between parties on the nationalism scale would increase by $50 \%$ the chances of an individual supporting secession relative to other territorial preferences $\left(\mathrm{H}_{1 \mathrm{a}}\right)$. Similarly, a one-point increase in perceived distance between each voter and all the political parties would raise their probability of supporting secession by $136 \%\left(\mathrm{H}_{1 b}\right)$. This significant positive effect is generally constant across different types of models' specifications and different operationalizations of the dependent variable. The positive effect remains constant in spite of the influence of other common explanations (like economic criticism and being a Catalan speaker).

We should report an unexpected change of direction in the horizontal polarization effect (Model 3 in Table A2 in the Supplementary File) when both dimensions (horizontal and vertical) are included in the model simultaneously. None of the other specifications of the model produce this change. There are no signs of collinearity in this model and the correlation between the two dimensions is moderate (0.4). Given that both factors are based on the same original index, it seems that the vertical indicator is better at capturing the influence on support for secession.

However, this unexpected negative drift of the horizontal indicator disappears when we test the interaction effect between polarization and identity (Model 4 in the Supplementary File). The significant positive effects of both indicators of polarization are constant across different specifications of the interaction model and give empirical support to $\mathrm{H}_{3}$. Moreover, the measures of fit suggest that this interaction model fits better than the models without interaction. Hence, as we expected, identity multiplies polarization's effect on support for secession. In Figure 6, we can observe this effect through the predictive values of the dependent variables estimated for the interaction in Model 4. It is interesting to note that the interaction between horizontal polarization and identity shows that having only or predominantly a Catalan identity made regionalist voters more receptive of regionalist parties, while among those regionalist voters who claimed to feel as Spanish as Catalan (or more Spanish), the horizontal polarization effect progressively reduced their support.

Regarding non-regionalist voters, the effect of both horizontal $\left(\mathrm{H}_{2 \mathrm{a}}\right)$ and vertical $\left(\mathrm{H}_{2 \mathrm{a}}\right)$ polarization indicators is negative, but as we expected the coefficients are statistically non-significant and, in the case of the horizontal dimension, almost zero. This result is robust to different specifications, including the simple version (with each polarization index as the only dependent variable) and the introduction of the interaction with identity.



Figure 5. Average marginal effects of horizontal and vertical polarization on support for independence in 2012 by types of parties. Notes: The complete results of the models can be found in Tables A2 and A3 in the Appendix (Models 1, 2, 5 and 6). 

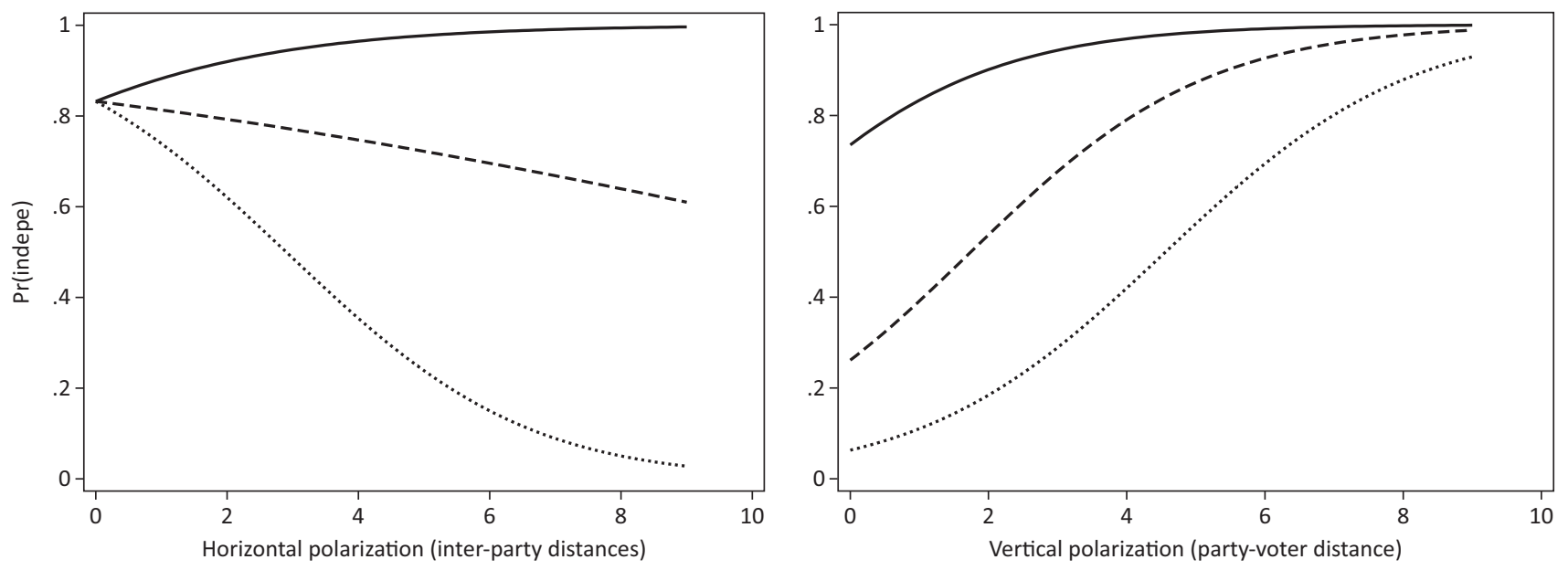

$$
\text { _ Only Catalan _ _ _ - More Catalan than Spanish .......... As Catalan as Spanish }
$$

Figure 6. Predicted probabilities of support for independence among voters from regionalist parties given different levels of polarization by national identity. Notes: Predicted probabilities are based on Model 4; see Table A2 in the Appendix for the complete results.

This result suggests that polarization produced a different outcome among non-regionalist voters: Although some of the more polarized were apparently among those against secession, many non-polarized voters also opposed it (a dynamic that was less frequent in the case of regionalist voters).

Given that the 2012 election experienced a significant degree of volatility among the parties (17.2 points, the highest since 1988), polarization might have stimulated party switching. Hence, a significant proportion of non-regionalist voters who voted for PSC in 2010 switched to ERC two years later (Rico \& Liñeira, 2014). In this case, we may be facing a problem of self-selection bias, because polarization is hiding the effect of vote switching, focusing only on voters who had already switched to a different party because of their territorial preferences. In response to this potential problem, we have checked the effect of the models over different sets of the electorate, distinguishing them according to whom they reported voting for in 2010 (the coefficients are not presented here). Significantly, the main results of our variables regarding polarization remain constant. Even the change of direction experienced by horizontal polarization among regionalist voters in Model 3 disappears, as it maintains the same significant positive direction. Thus, the results of our expectation are robust to the definition of the subset of voters (2012 vote or 2010 vote).

Alternatively, our findings may simply indicate that polarization is necessarily connected to greater support for secessionist positions among regionalist voters. To consider this potential counterargument, we run the same models with a post-electoral survey conducted after the 2010 election (the coefficients are not presented here). The results show a weaker role of polarization in explaining support for independence among regionalist voters. Although vertical polarization still yields significant results, the coefficient is much lower than in 2012, in some cases approaching zero, particularly when identity is introduced as a factor. In addition, horizontal polarization is constantly non-significant and close to zero. We find the same outcome for non-regionalist voters, whose coefficients are almost zero and non-significant. Overall, these results indicate that polarization was irrelevant in explaining individuals' attitudes towards independence in 2010. The results are consistent with what we expected from the party strategies implemented to date. Although by $2010 \mathrm{CiU}$ had evolved a more critical position regarding the issue, its strategy was still far from being a pro-secession position, while ERC continued to emphasize social issues (the party had been in the government since 2003). Only the new pro-secession electoral coalition Solidaritat Catalana per la Independència (SI, Catalan Solidarity for Independence) was explicitly supporting independence as a central issue, but the sample of its voters in the survey was too small to check the hypothesis.

\section{Conclusion}

The literature analysing support for secession has usually relied on structural factors to explain the prevalence of claims for independence over time. However, Catalonia offers a challenging case of a sudden, rapid rise in such claims in a narrow span of time, for which agency factors-particularly the role of parties and leaderscould provide more useful explanations. We have suggested a two-step process. First, given that Catalan regionalist parties had progressively adopted more radical positions regarding the centre-periphery cleavage over the course of the decade (as has been stated by previous works), these centrifugal strategies were 
perceived by the electorate as drivers of growing polarization. Indeed, we have provided empirical evidence of a smooth increase in polarization among the electorate, particularly between 2006 and 2012. Second, when the parties strengthened their outbidding competition around 2012, transforming their platforms and their messages to explicitly pledge their support for secession, many of their voters were more likely to follow the cue and give their support to independence as well. After measuring perceived polarization at the horizontal level (between parties) and the vertical level (between parties and voters) in the national cleavage, this article has shown that both dimensions of polarization were significantly related to an increase in support for secession and voting for the applicable parties among regionalist voters, but not necessarily among non-regionalist ones.

This article is a first step to observe the political consequences of centrifugal strategies and polarization in the nationalist dimension for the territorial preferences of the electorate in a context of great significance in the centre-periphery cleavage. Furthermore, Guntermann and Blais (2020) are among those to have suggested that moderate voters may finally be persuaded to take sides in a context of high elite polarization, based on analysing data from 2017, by which time polarization had spread throughout the electorate. Our study suggests that, at the beginning of this political process, such alignment only occurred among the most polarized voters and not necessarily in the two-party blocks. Future studies should observe what happened in the interim and how the polarization of both elites and voters evolved in parallel, along with the consequences. Accordingly, more attention should be given to those parties that adopted more centrifugal strategies, like Ciudadanos, in order to ascertain how they could benefit from this polarization.

\section{Acknowledgments}

We would like to thank the three reviewers for their very helpful comments and the editors for their support during the process.

\section{Conflict of Interests}

The authors declare no conflict of interests.

\section{Supplementary Material}

Supplementary material for this article is available online in the format provided by the authors (unedited).

\section{References}

Álvarez Pereira, B., Portos, M., \& Vourdas, J. (2018). Waving goodbye? The determinants of autonomism and secessionism in Western Europe. Regional Studies, 52(2), 197-211. https://doi.org/10.1080/00343404. 2017.1282609
Balcells, L., Fernández-Albertos, J., \& Kuo, A. (2021). Secession and social polarization: Evidence from Catalonia (WIDER Working Paper 2/2021). United Nations University World Institute for Development. https://doi.org/10.35188/UNU-WIDER/2021/936-5

Barrio, A., Barberà, O., \& Rodríguez-Teruel, J. (2018). "Spain steals from us!" The "populist drift" of Catalan regionalism. Comparative European Politics, 16(6), 993-1011. https://doi.org/10.1057/s41295018-0140-3

Barrio, A., \& Rodríguez-Teruel, J. (2014). Pour quelles raisons les partis politiques en Catalogne se sont-ils radicalisés? Le système des partis et la montée du souverainisme (1999-2012) [Why are political parties in Catalonia radicalized? Party system and the rise of souverainism (1999-2012)]. Pôle Sud, 40, 99-119.

Barrio, A., \& Rodríguez-Teruel, J. (2017). Reducing the gap between leaders and voters? Elite polarization, outbidding competition, and the rise of secessionism in Catalonia. Ethnic and Racial Studies, 40(10), 1776-1794. https://doi.org/10.1080/ 01419870.2016 .1213400

Bischof, D., \& Wagner, M. (2019). Do voters polarize when radical parties enter parliament? American Journal of Political Science, 63(4), 888-904. https:// doi.org/10.1111/ajps.12449

Blais, A., Nadeau, R., \& Blais, A. (1992). To be or not to be sovereignist: Quebeckers' perennial dilemma. Canadian Public Policy/Analyse de Politiques, 18(1), 89-103. https://doi.org/10.2307/3551558

Bolsen, T., Druckman, J. N., \& Cook, F. L. (2014). The influence of partisan motivated reasoning on public opinion. Political Behavior, 36(2), 235-262. https:// doi.org/10.1007/s11109-013-9238-0

Bond, R. (2000). Squaring the circles: Demonstrating and explaining the political "non-alignment" of Scottish national identity. Scottish Affairs, 32(1), 15-35. https://doi.org/10.3366/scot.2000.0029

Brancati, D. (2006). Decentralization: Fueling the fire or dampening the flames of ethnic conflict and secessionism? International Organization, 60(3), 651-685.

Bullock, J. G. (2020). Party cues. In E. Suhay, B. Grofman, \& A. H. Trechsel (Eds.), The Oxford handbook of electoral persuasion (pp. 128-150). Oxford University Press. https://doi.org/10.1093/oxfordhb/ 9780190860806.013.2

Campbell, J. E. (2016). Polarized: Making sense of a divided America. Princeton University Press.

Coakley, J. (2008). Ethnic competition and the logic of party system transformation. European Journal of Political Research, 47(6), 766-793. https://doi.org/ 10.1111/j.1475-6765.2008.00824.x

Colino, C. (2009). Constitutional change without constitutional reform: Spanish federalism and the revision of Catalonia's Statute of Autonomy. Publius, 39(2), 262-288.

Colino, C. (2020). Decentralization in Spain: Federal evolution and performance of the Estado Autonómico. 
In D. Muro \& I. Lago (Eds.), The Oxford handbook of Spanish politics (pp. 62-81). Oxford University Press.

Collier, P., \& Hoeffler, A. (2002). The political economy of secession. In H. Hannum \& E. F. Babbitt (Eds.), Negotiating self-determination (pp. 37-59). Lexington Books.

Colomer, J. M. (2018). The venturous bid for the independence of Catalonia. Revista de Estudios Políticos, 179, 267-294. https://doi.org/10.1080/00905992. 2017.1293628

Cox, G. W. (1990). Centripetal and centrifugal incentives in electoral systems. American Journal of Political Science, 34(4), 903-935. https://doi.org/10.2307/ 2111465

Dalton, R. J. (2008). The quantity and the quality of party systems party system polarization, its measurement, and its consequences. Comparative Political Studies, 41(7), 899-920. https://doi.org/10.1177/ 0010414008315860

de Lange, S. L. (2012). New alliances: Why mainstream parties govern with radical right-wing populist parties. Political Studies, 60(4), 899-918. https://doi. org/10.1111/j.1467-9248.2012.00947.x

de Vries, C. E., \& Hobolt, S. B. (2020). Political entrepreneurs. The rise of challenger parties in Europe. Princeton University Press.

Dejaeghere, Y., \& Dassonneville, R. (2017). A comparative investigation into the effects of party-system variables on party switching using individual-level data. Party Politics, 23(2), 110-123. https://doi.org/ $10.1177 / 1354068815576294$

Dowling, A. (2018). The rise of Catalan independence: Spain's territorial crisis. Routledge.

Downes, J. F., \& Loveless, M. (2018). Centre right and radical right party competition in Europe: Strategic emphasis on immigration, anti-incumbency, and economic crisis. Electoral Studies, 54, 148-158. https:// doi.org/10.1016/j.electstud.2018.05.008

Druckman, J. N., Peterson, E., \& Slothuus, R. (2013). How elite partisan polarization affects public opinion formation. American Political Science Review, 107(1), 57-79. https://doi.org/10.1017/\$0003055 412000500

Elias, A. (2015). Catalan independence and the challenge of credibility: The causes and consequences of CataIan nationalist parties' strategic behavior. Nationalism and Ethnic Politics, 21(1), 83-103. https://doi. org/10.1080/13537113.2015.1003490

Elias, A., \& Mees, L. (2017). Between accommodation and secession: Explaining the shifting territorial goals of nationalist parties in the Basque Country and Catalonia. Revista d'Estudis Autonomics i Federals, 25, 129-165. https://doi.org/10.2436/20.8080.01.17

Ezrow, L. (2007). The variance matters: How party systems represent the preferences of voters. The Journal of Politics, 69(1), 182-192. https://doi.org/ 10.1111/j.1468-2508.2007.00503.x

Flora, P., Kuhnle, S., \& Urwin, D. W. (Eds). (2007).
State formation, nation-building, and mass politics in Europe: The theory of Stein Rokkan, based on his collected works. Oxford University Press.

Gormley-Heenan, C., \& Macginty, R. (2008). Ethnic outbidding and party modernization: Understanding the Democratic Unionist Party's electoral success in the post-agreement environment. Ethnopolitics, 7(1), 43-61. https://doi.org/10.1080/17449050701846865

Gray, C. (2020). Territorial politics and the party system in Spain. Continuity and change since the financial crisis. Routledge.

Griffiths, R. D. (2016). Age of secession. The international and domestic determinants of state birth. Cambridge University Press.

Guntermann, E. (2017). Party influence where predispositions are strong and party identification is weak: Assessing citizens' reactions to party cues on regional nationalism in Spain. Party Politics, 25(4), 609-620. https://doi.org/10.1177/1354068817736756

Guntermann, E., \& Blais, A. (2020). When faced with elite polarization, citizens take sides: The 2017 election in Catalonia. Regional and Federal Studies. Advance online publication. https://doi.org/10.1080/1359 7566.2020.1801648

Hale, H. E. (2008). The foundations of ethnic politics. Separatism of states and nations in Eurasia and the world. Cambridge University Press.

Hechter, M. (2000). Containing nationalism. Oxford University Press.

Hellström, J. (2008). Who leads, who follows? Re-examining the party-electorate linkages on European integration. Journal of European Public Policy, 15(8), 1127-1144. https://doi.org/10.1080/ 13501760802407649

Hetherington, M. J., \& Weiler, J. (2010). Authoritarianism and polarization in American politics. Cambridge University Press.

Hierro, M. J., \& Queralt, D. (2021). The divide over independence: Explaining preferences for secession in an advanced open economy. American Journal of Political Science, 65(2), 422-442. https://doi.org/10.1111/ ajps. 12549

Horowitz, D. L. (1985). Ethnic groups in conflict. University of California Press.

Keating, M., \& Wilson, A. (2009). Renegotiating the state of autonomies: Statute reform and multi-level politics in Spain. West European Politics, 32(3), 536-558.

Lauka, A., McCoy, J., \& Firat, R. B. (2018). Mass partisan polarization: Measuring a relational concept. American Behavioral Scientist, 62(1), 107-126. https://doi. org/10.1177/0002764218759581

Lupia, A. (1994). Shortcuts versus encyclopedias: Information and voting behavior in California insurance reform elections. American Political Science Review, 88(1), 63-76. https://doi.org/10.2307/2944882

Lupu, N. (2015). Party polarization and mass partisanship: A comparative perspective. Political Behavior, 37(2), 331-356. https://doi.org/10.1007/s11109- 
014-9279-z

Martí, D. (2013). The 2012 Catalan election: The first step towards independence? Regional \& Federal Studies, 23(4), 507-516. https://doi.org/10.1080/13597566. 2013.806302

Massetti, E., \& Schakel, A. H. (2013). Ideology matters: Why decentralisation has a differentiated effect on regionalist parties' fortunes in Western democracies. European Journal of Political Research, 52(6), 797-821. https://doi.org/10.1111/1475-6765. 12015

McCrone, D., \& Paterson, L. (2002). The conundrum of Scottish independence. Scottish Affairs, 40, 54-75.

Miley, T. J. (2014). Democratic representation and the national dimension in Catalan and Basque politics. International Journal of Politics, Culture and Society, 27(3), 291-322. https://doi.org/10.1007/ s10767-013-9159-2

Mitchell, P., Evans, G., \& O’Leary, B. (2009). Extremist outbidding in ethnic party systems is not inevitable: Tribune parties in Northern Ireland. Political Studies, 57(2), 397-421. https://doi.org/10.1111/j.14679248.2008.00769.x

Morales, L., Pardos-Prado, S., \& Ros, V. (2015). Issue emergence and the dynamics of electoral competition around immigration in Spain. Acta Politica, 50(4), 461-485. https://doi.org/10.1057/ap.2014.33

Muñoz, J., \& Tormos, R. (2015). Economic expectations and support for secession in Catalonia: Between causality and rationalization. European Political Science Review, 7(2), 315-341. https://doi.org/ 10.1017/S1755773914000174

Nord $\varnothing, \AA$. D. (2021). Do voters follow? The effect of party cues on public opinion during a process of policy change. Scandinavian Political Studies, 44(1), 45-66. https://doi.org/10.1111/1467-9477.12187

Orte, A., \& Wilson, A. (2009). Multi-level coalitions and statute reform in Spain. Regional and Federal Studies, 19(3), 415-436. https://doi.org/10.1080/ 13597560902957500

Pagoaga Ibiricu, I. (2020). Party competition during secession crises in advanced democracies. Regional and Federal Studies. Advance online publication. https:// doi.org/10.1080/13597566.2020.1824994

Paz, R. (2012, November 17). Rajoy intenta camuflar su preocupación por Cataluña [Rajoy attempts to camouflage his concern about Catalonia]. El Periódico Mediterráneo. https://www.elperiodico mediterraneo.com/espana/2012/09/17/rajoycamuflar-preocupacion-cataluna-42086270.html

Rabushka, A., \& Shepsle, K. A. (1972). Politics in plural societies: A theory of democratic instability. Merrill.

Rico, G., \& Liñeira, R. (2014). Bringing secessionism into the mainstream: The 2012 regional election in Catalonia. South European Society and Politics, 19(2), 257-280. https://doi.org/10.1080/13608746. 2014.910324

Rodríguez-Teruel, J. (2021). Polarisation and electoral realignment: The case of the right-wing parties in Spain. South European Society and Politics, 25(3/4), 381-410. https://doi.org/10.1080/13608746.2021. 1901386

Sanjaume-Calvet, M., \& Riera-Gil, E. (2020). Languages, secessionism and party competition in Catalonia: A case of de-ethnicising outbidding? Party Politics. Advance online publication. https://doi.org/ 10.1177/1354068820960382

Sartori, G. (1976). Parties and party systems: A framework for analysis (Vol. 1). Cambridge University Press.

Schmitt, J. (2016, July 10-13). How to measure ideological polarization in party systems [Paper presentation]. ECPR Graduate Student Conference, Tartu, Estonia. https://ecpr.eu/Events/Event/PaperDetails/ 28307

Serrano, I. (2013). Just a matter of identity? Support for independence in Catalonia. Regional \& Federal Studies, 23(5), 523-545. https://doi.org/10.1080/ 13597566.2013.775945

Steenbergen, M. R., Edwards, E. E., \& de Vries, C. E. (2007). Who's cueing whom? Mass-elite linkages and the future of European integration. European Union Politics, 8(1), 13-35. https://doi.org/10.1177/ 1465116507073284

Szöcsik, E., \& Polyakova, A. (2018). Euroscepticism and the electoral success of the far right: The role of the strategic interaction between center and far right. European Political Science, 18, 400-420. https://doi. org/10.1057/s41304-018-0162-y

Wood, J. R. (1981). Secession: A comparative analytical framework. Canadian Journal of Political Science, 14(1), 107-134.

Zuber, C. I., \& Szöcsik, E. (2015). Ethnic outbidding and nested competition: Explaining the extremism of ethnonational minority parties in Europe. European Journal of Political Research, 54(4), 784-801. https://doi. org/10.1111/1475-6765.12105

\section{About the Authors}

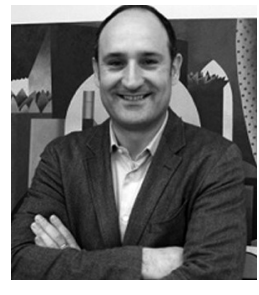

Juan Rodríguez-Teruel is an associated professor at the University of Valencia. He has also been lecturer at the Autonomous University of Barcelona and visiting fellow at the London School of Economics, Edinburgh, Leiden, Nottingham, and Université Libre de Bruxelles. His main areas of research are political elites, party politics, and executive politics. He is author of Ministers in Democratic Spain (Linz Award 2007, in Spanish). His work has been published in South European Politics and Society, Ethnic and Racial Studies, Comparative European Politics, Acta Politica and Contemporary Sociology. He is founding editor of the political website Agenda Pública. 


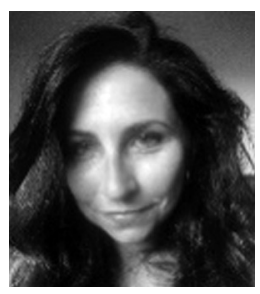

Astrid Barrio is an associated professor at University of Valencia. She has also been lecturer at the Autonomous University of Barcelona. Her main fields of research are political parties, populism, Spanish politics, and Catalan nationalism. Her work has been published in South European Politics and Society, Ethnic and Racial Studies, Comparative European Politics, and Mediterranean Politics. 